JURNAL PENDIDIKAN, p-ISSN 2715-095X, e-ISSN 2686-5041

Volume 30, No.3, Nopember 2021 (499-514)

Online: http://journal.univetbantara.ac.id/index.php/jp

\title{
Menggunakan Quizizz untuk Meningkatkan Prestasi Belajar Bahasa Indonesia
}

\author{
Suwarto \\ Universitas Veteran Bangun Nusantara Sukoharjo, E-mail: suwartowarto@yahoo.com
}

Received: Oktober 24, $2021 \quad$ Accepted: Oktober 30, $2021 \quad$ Online Published: Nopember 08, 2021

\begin{abstract}
Abstrak: Penelitian ini bertujuan untuk meningkatkan prestasi belajar bahasa Indonesia siswa dengan menggunakan Quizizz. Penelitian ini menggunakan penelitian tindakan kelas dengan dua siklus. Terdapat tiga kali pertemuan dalam setiap siklusnya. Subjek penelitian ini adalah 22 siswa kelas 8A SMP MTA Gemolong Sragen, Jawa Tengah. Para peneliti menggunakan tiga instrumen untuk mengumpulkan data, yaitu tes, lembar observasi, dan kuesioner. Hasil penelitian menunjukkan bahwa prestasi belajar bahasa Indonesia siswa dapat ditingkatkan dengan menggunakan Quizizz. Peningkatan nilai rata-rata hasil pre-tes dari 57,73 dan pos-tes 75 pada siklus I, dan nilai rata-rata pre-tes 60,00 dan pos-tes 81,36 pada siklus II. Hasil uji-t pada siklus I dan siklus II signifikan, sedangkan persentase ketuntasan pada pra siklus, siklus I, dan siklus II juga meningkat secara signifikan.
\end{abstract}

Kata-kata Kunci : Quizizz, prestasi belajar bahasa Indonesia

\section{Using Quizizz to Improve Indonesian Learning Achievement}

\author{
Suwarto \\ Veteran Bangun Nusantara University, Sukoharjo,E-mail: suwartowarto@yahoo.com
}

\begin{abstract}
This study aims to improve students' Indonesian learning achievement by using Quizizz. This research uses classroom action research with two cycles. There are three meetings in each cycle. The subjects of this study were 22 students of class 8A SMP MTA Gemolong Sragen, Central Java. The researchers used three instruments to collect data, namely tests, observation sheets, and questionnaires. The results showed that students' Indonesian learning achievement could be improved by using Quizizz. The average score of the pre-test results increased from 57.73 and the post-test to 75 in the first cycle, and the pre-test mean score was 60.00 and the post-test was 81.36 in the second cycle. The results of the t-test in cycle I and cycle II were significant, while the percentage of completeness in the pre-cycle, cycle I, and cycle II also increased significantly.
\end{abstract}

Keywords: Quizizz, Indonesian learning achievement 


\section{Pendahuluan}

Penggunakan aplikasi mobile di abad ke-21 adalah hal yang biasa (Alsuhaymi \& Alghamdi, 2021). Banyak guru menggunakan Informasi Teknologi (IT) untuk membantu mereka dalam proses belajar-mengajar. Teknologi baru menawarkan kesempatan untuk melibatkan siswa dalam belajar dengan cara baru. Paradigma pedagogis yang modern akan diperkuat oleh guru karena mereka menggunakan Informasi dan Teknologi Komunikasi selama proses belajar mengajar (Khafaga \& Shaalan, 2021). Saat ini, virus Corona (Covid-19) menjadi wabah di tahun 2019 telah mempengaruhi pembelajaran seluruh dunia, termasuk proses belajar-mengajar. Sistem belajar-mengajar telah berubah dari offline ke pembelajaran online. Pembelajaran online adalah salah satu bentuk pembelajaran berbasis IT yang sedang diterapkan saat ini, dan telah menjadi pendekatan yang populer untuk pembelajaran yang efektif di masyarakat akademik secara luas (Rios et al, 2018.). Banyak masalah telah ditemukan terkait dengan siswa khususnya keterampilan berbahasa yang mendasar. Membaca merupakan salah satu dari empat keterampilan berbahasa yang esensial yang harus dikuasai (Peng et al., 2020). Namun, isu yang teridentifikasi adalah bahwa siswa kurang minat dalam belajar membaca (Gupta \& Woldemariam, 2011). Karena itu, siswa mungkin kurang memahami makna eksplisit dan implisit yang terkandung dalam sebuah teks, yang membuat prestasi membaca mereka sehari-hari stagnan. Siswa merasa metode konvensional yang digunakan guru dalam proses belajar mengajar membosankan dan kehilangan minat untuk belajar (Mobinizad, 2018). Mengingat permasalahan yang telah teridentifikasi dalam pembelajaran bahasa Indonesia tentang keterampilan membaca siswa, studi ini terfokus pada pemahaman bacaan untuk menemukan metode baru yang dapat digunakan untuk meningkatkan keterampilan membaca siswa.

Banyak metode yang produktif secara bersamaan dapat digunakan untuk mengelola kecemasan siswa dan meningkatkan pemahaman membaca siswa (Zaccoletti et al., 2020). Namun, masalah ini studi yang menawarkan metode lain untuk membantu guru di dalam proses pembelajaran. Saat ini, mengingat bahwa siswa milenial tidak dapat dipisahkan dari bidang IT, terutama yang smartphone, sehingga diusulkan bahwa salah satu metode baru yang potensial untuk memotivasi siswa untuk belajar adalah melalui gamification (Alhuwaydi, 2020).

Gamifikasi adalah penggunaan game dalam konteks non-game (Deterding et al., 2011). Menurut Kapp, gamifikasi diterapkan untuk memotivasi, mendorong pembelajaran, memecahkan masalah, dan melibatkan orang dalam pembelajaran (Kapp, 2012). Dengan kata lain, gamifikasi adalah menggabungkan konten, permainan, dan teknologi yang bertujuan untuk memotivasi pengalaman belajar siswa di kelas selama proses belajar mengajar. Teknologi digital diyakini dapat meningkatkan minat siswa dan memungkinkan mereka untuk lebih fokus pada proses belajar mengajar di kelas (Mobinizad, 2018; Pourhosein Gilakjani \& Sabouri, 2016). Selain itu, penggunaan teknologi ini tidak hanya diharapkan dapat meningkatkan minat belajar siswa, tetapi juga terutama meningkatkan prestasi membaca mereka (Loewen et al., 2019). Studi lain juga mendukung gagasan bahwa mempraktikkan teknologi digital dapat meningkatkan motivasi siswa (Peters \& Bodkin, 2021). 
Ada perangkat lunak atau sebuah aplikasi untuk gamifikasi, seperti Kahoot, Quizizz, Duolingo, FlipQuiz, dan sebagainya (Juniarta et al., 2020). Namun, dalam studi ini, para peneliti memilih untuk fokus pada penggunaan Quizizz sebagai sebuah pembelajaran media. Quizizz adalah platform e-learning yang menggabungkan elemen desain game dengan pertanyaan mandiri dan umpan balik instan untuk membantu siswa belajar (Pitoyo et al., 2020). Ini adalah alat penilaian online yang disajikan sebagai aktivitas kelas multipemain yang menyenangkan yang memungkinkan semua siswa untuk berlatih bersama dengan komputer, Smartphone, dan iPad mereka (Yan mei et al., 2019). Selanjutnya, penelitian ini bertujuan untuk menyelidiki efektivitas Quizizz dalam membantu siswa untuk meningkatkan keterampilan pemahaman membaca mereka. Quizizz dapat digunakan dimana saja dan kapan saja dengan koneksi internet. Artinya, siswa dapat menggunakan Quizizz di luar kelas selama perangkat terhubung ke internet. Dengan banyak latihan, diharapkan keterampilan membaca siswa meningkat (Mohamad et al., 2020) .

Penelitian penggunaan Quizizz sebagai media belajar untuk membaca pemahaman telah dilakukan oleh Nanda (Nanda et al., 2018). Penelitian ini menggunakan desain praeksperimen sebagai metodologi penelitian untuk mengukur penggunaan aplikasi Quizizz dalam meningkatkan kemampuan membaca. Berdasarkan penelitiannya, dia menemukan bahwa siswa mereka kemampuan membaca meningkatkan setelah pre-test dan post-test dengan menggunakan Quizizz.

Penelitian lain dilakukan oleh Juniarta et al. (2020). Mereka menggunkan desain penelitian tindakan kelas untuk menyelidiki peningkatan prestasi membaca siswa dengan menerapkan pembelajaran terpadu dengan menggunakan Quizizz. Studi ini menemukan bahwa skor rata-rata prestasi membaca siswa meningkat secara signifikan setelah menggunakan Quizizz. Ini berarti bahwa menggunakan Quizizz dapat meningkatkan prestasi membaca siswa. Selanjutnya, meskipun penggunaan Quizizz untuk meningkatkan pembelajaran pemahaman membaca siswa telah dieksplorasi oleh banyak penelitian, tidak ada penelitian yang memecahkan masalah ini dapat ditemukan. Oleh karena itu, penelitian ini bermaksud untuk memeriksa penggunaan Quizizz untuk meningkatkan pembelajaran pemahaman membaca siswa.

Mempertimbangkan masalah penggunaan metodologi pengajaran, penelitian ini bertujuan untuk menyelidiki penggunaan Quizizz sebagai metode baru untuk meningkatkan prestasi belajar bahasa Indonesia siswa. Berdasarkan latar belakang sebelumnya, maka pertanyaan penelitian dirumuskan sebagai berikut: "Bagaimana penerapan penggunaan Quizizz untuk meningkatkan prestasi belajar bahasa Indonesia siswa?"

Membaca adalah suatu proses melihat dan memahami isi suatu wacana, baik secara nyaring maupun dalam hati. Lebih lanjut, pemahaman membaca dapat didefinisikan sebagai kemampuan untuk memahami teks, menganalisis informasi, dan menafsirkan dengan benar apa yang dikatakan penulis. Membaca adalah suatu bagian dari pendidikan yang terlibat dalam konteks akademik, di mana pembaca mendapatkan proses belajar dari apa yang mereka baca (Grabe, 2009). Membaca berguna untuk pemerolehan bahasa. Membaca pemahaman adalah kompleks kemampuan yang melibatkan beberapa tugas. Untuk dapat memahami apa yang dibaca, dibutuhkan orang untuk menjadi akrab dengan struktur teks dan topik, serta menyadari dengan strategi membaca, bagaimana menggunakan strategi ini dalam pengolahan bahan, dan pengenalan kata (Pang, 2008). 
Keterampilan membaca adalah salah satu dari empat keterampilan bahasa yang mendasar yang harus dikuasai oleh siswa. Penguasaan keterampilan membaca dapat meningkatkan keterampilan berbahasa lainnya. Membaca adalah aktivitas yang diperlukan dalam kehidupan yang dapat memperbarui pengetahuan (Aritonang et al., 2019). Untuk alasan ini, keterampilan membaca merupakan alat penting untuk keberhasilan akademik. Oleh karena itu , membaca adalah kegiatan yang paling penting dalam setiap kelas bahasa, tidak hanya sebagai sumber informasi atau kegiatan yang menyenangkan tetapi juga sebagai sarana untuk mengkonsolidasikan dan memperluas pengetahuan seseorang tentang bahasa. Membaca sangat penting untuk memperluas wawasan dan memahami budaya.

Basirun (2004) mengidentifikasi beberapa indikator umum dalam pemahaman bacaan, sebagai berikut: (1) Menemukan ide dari sebuah ayat tertentu; (2) Menjawab pertanyaan " $5 \mathrm{~W}+1 \mathrm{H}$ ” (What, Who, Why, Where, When, dan How) tentang ide pokok; (3) Menjawab pertanyaan tentang informasi tertentu; (4) Melengkapi kalimat dengan menggunakan kata tertentu dari teks; 5) Menjawab pertanyaan " $5 \mathrm{~W}+1 \mathrm{H}$ " dengan menggunakan informasi tertentu; (6). Menemukan sinonim dan antonim dari kata tertentu; (7) Menemukan arti kata tertentu; (8) Menemukan informasi eksplisit dan implisit; (9) Menyimpulkan teks; dan (10) Menemukan referensi kata dalam teks. Indikatorindikator tersebut menyiratkan bahwa memahami sebuah teks bacaan tidak sesederhana yang kita lihat.

Saat ini, penggunaan teknologi mobile tidak terbatas pada pengiriman pesan singkat, chatting, panggilan video, surfing web, dan sebagainya . Bidang pendidikan juga sudah mulai menggunakan teknologi mobil untuk membantu proses belajarmengajar (Villaflor, 2019). Pembelajaran Bahasa Berbantuan Seluler (MALL) berkaitan dengan penggunaan teknologi seluler dalam pembelajaran bahasa. MALL dianggap sebagai cara baru belajar bahasa yang memungkinkan pelajar untuk belajar dengan menggunakan perangkat mobil mereka di luar kelas (Kukulska-Hulme, 2009; Kukulska-Hulme \& Bull, 2009; Wang \& Higgins, 2006). Para siswa tidak perlu duduk di kelas atau di depan komputer mereka untuk belajar bahasa. MALL memungkinkan pengguna yang termotivasi untuk belajar bahasa secara mandiri kapanpun dan dimanapun (Barakati, 2013; Lai \& Zheng, 2018). Artinya dengan menggunakan perangkat mobil, siswa memiliki kesempatan untuk belajar di mana saja dan kapan saja mereka mau (Khafaga \& Shaalan, 2021). Kukulska-Hulme, \& Bull (2009) juga menunjukkan bahwa penggunaan perangkat mobil diharapkan memiliki potensi yang cukup besar untuk mencapai tujuan dan kebutuhan belajar individu dan memberikan lebih banyak kesempatan untuk belajar di luar kelas. Semakin banyak mereka memiliki kesempatan untuk belajar, semakin mereka dapat memahami apa yang mereka pelajari. Karena penggunaan metode MALL, proses belajarmengajar tidak terbatas pada belajar di dalam kelas. Juga, Kolb (2011) percaya bahwa perangkat seluler dapat membantu siswa untuk belajar lebih efektif, dan mereka mungkin menganggap tugas-tugas MALL menyenangkan (Davie \& Hilber, 2015). Mengingat perangkat mobil telah menjadi bagian dari gaya hidup siswa, penggunaan metode pembelajaran ini kemungkinan besar akan cocok untuk mereka. Perangkat seluler dapat dianggap sebagai mainan yang dapat diubah menjadi alat belajar (Kolb, 2008). 
Gamifikasi adalah penggunaan mekanisme berbasis permainan dan pemikiran permainan untuk melibatkan siswa, memotivasi tindakan, mempromosikan pembelajaran, dan memecahkan masalah (Kapp, 2012). Sementara itu, Deterding dkk. (2011) mendefinisikan gamifikasi sebagai penggunaan elemen desain game dalam konteks nongame, yang cukup baru dan berkembang pesat. Selain itu, Prensky mencatat bahwa fitur permainan dapat memberikan bagian hiburan dari desain pendidikan yang diperlukan untuk melibatkan pelajar (Prensky, 2001). Dengan demikian, gamifikasi telah menjadi metode potensial yang dapat digunakan untuk memotivasi siswa untuk belajar. Metode ini diharapkan dapat membantu siswa untuk meningkatkan prestasi belajarnya. Menggunakan alat komunikasi audio, video, dan seluler berdampak positif pada pengalaman belajar online siswa (Rios et al., 2018). Menurut Hamari dkk. (2014), sebuah penelitian baru-baru ini penelitian gamifikasi akademik menemukan bahwa kebanyakan studi pada subjek diverifikasi bahwa gamifikasi dapat bekerja, meskipun memiliki efek yang berbeda.

Quizizz adalah platform e-learning yang menggabungkan elemen desain game dengan pertanyaan mandiri dan umpan balik instan untuk membantu siswa belajar untuk penguasaan (Zhao, 2019). Mei dkk. (2019) mengatakan bahwa Quizizz adalah alat penilaian online sebagai kegiatan kelas menyenangkan multiplayer yang memungkinkan semua siswa untuk berlatih dengan komputer mereka, Smartphone, dan iPad. Wibawa, Astuti, dan Pangestu percaya bahwa Quizizz merupakan media yang dapat memotivasi siswa dalam proses belajar-mengajar dengan fitur yang menarik (Wibawa et al., 2019). Quizizz adalah didesain untuk siswa melakukan apa saja, di mana pertanyaan muncul di layar masing-masing siswa, sehingga mereka dapat menjawab pertanyaanpertanyaan dengan langkah mereka sendiri, dan meninjau jawaban mereka di akhir (Mohamad et al., 2020). Quizizz memiliki dua mode aplikasi yang berbeda. Ini dapat digunakan secara real-time di kelas atau diberikan sebagai pekerjaan rumah. Artinya dengan menggunakan Quizizz, guru dapat membuat kuis yang dapat digunakan untuk pretest, penilaian formatif, post-test, dan pekerjaan rumah.

Seperti kebanyakan aplikasi gamifikasi, Quizizz juga gratis untuk diunduh. Quizizz adalah platform permainan yang fleksibel, di mana setiap guru dapat menggunakannya untuk area konten apa pun yang mereka ajar (Wibawa et al., 2019). Ini juga memiliki bagian Blog yang menyoroti fitur atau teknik baru untuk menggunakan platform. Dengan menggunakan Quizizz, guru tidak perlu memproyeksikan pertanyaan di papan atau layar karena setiap siswa memiliki akses ke gameplay tanya jawab mereka. Guru juga dapat menambahkan pertanyaan yang ada dari Quizizz lain untuk nya memiliki Quizizz dengan 1-klik dan membuat suntingan. Keuntungan lain menggunakan Quizizz adalah guru dapat melihat laporan siswa dan pertanyaan mana yang dijawab dengan benar dan salah. Dengan demikian, guru dapat menginformasikan instruksi pada siswa yang sedang belajar (Zhao, 2019). Quizizz juga dapat diintegrasikan ke dalam Google Classroom. Soal-soal dalam Quizizz diacak secara otomatis untuk setiap siswa sehingga siswa tidak dapat mencontek satu sama lain. Setelah siswa menjawab pertanyaan, Meme menyenangkan ditambahkan. Ini dapat disesuaikan agar sesuai setiap masyarakat kelas, lingkungan sekolah, atau konten kelas, sebuah tes juga untuk memberikan umpan balik positif bagi mereka. Meskipun Quizizz adalah aplikasi gratis dan berbayar, menggunakan Quizizz masih membutuhkan akses internet yang mungkin perlu biaya untuk mengakses. Selain itu, Quizizz memiliki batasan jenis soal. Ini sempurna untuk fakta dan mengingat informasi, tetapi tidak menguntungkan untuk pertanyaan yang lebih rumit. Guru juga harus 
memastikan bahwa semua siswa memiliki perangkat sendiri karena platform ini dapat menjadi masalah ketika akses terbatas.

\section{Metode Penelitian}

Penelitian ini menggunakan penelitian tindakan kelas yang bertujuan untuk meningkatkan hasil belajar bahasa Indonesia siswa dengan menggunakan Quizizz. Penelitian tindakan kelas adalah kegiatan yang dilakukan oleh guru dengan orang lain atau peneliti yang bertujuan untuk meningkatkan kualitas proses pembelajaran di kelas (Priyanti et al., 2019). Ini menggunakan bentuk kolaborasi, di mana guru adalah mitra peneliti. Masing-masing dari mereka memfokuskan perhatian mereka pada aspek penelitian tindakan kelas sesuai dengan keahlian mereka: guru sebagai praktisi pembelajaran, dan para peneliti sebagai desainer dan pengamat kritis. Dalam pelaksanaannya, penelitian tindakan kelas ini menggunakan model Kurt Lewin dimana dalam satu siklus terdapat empat langkah utama , yaitu: (1). perencanaan, (2). tindakan, (3). observasi, dan (4). refleksi .

Langkah-langkahnya menurut Zhao (2019) adalah sebagai berikut: (1). Perencanaan. Perencanaan adalah persiapan yang dilakukan oleh peneliti untuk pelaksanaan penelitian tindakan kelas, seperti membuat rencana pelajaran, mempersiapkan permainan di dalam media Quizizz, membuat kuesioner dan lembar observasi, dan membuat pertanyaan pre-test dan post-test. (2). Aksi. Aksi mengacu pelaksanaan pembelajaran yang dipandu oleh rencana pelajaran yang telah dipersiapkan dengan Quizizz. Ada tiga kali pertemuan setiap siklusnya. Pertemuan pertama adalah pre-test dilanjutkan dengan pembelajaran. Proses pembelajaran dimulai dengan pengiriman kompetensi dasar dan indikator serta tujuan pembelajaran dan materi. Peneliti menjelaskan bagaimana menggunakan Quizizz untuk siswa. Selanjutnya, guru meminta siswa untuk menyelesaikan beberapa pertanyaan dalam Quizizz. Pertemuan terakhir dilakukan sebagai post-test. (3). Pengamatan. Observasi adalah kegiatan yang dilakukan peneliti untuk mengamati dampak dari tindakan yang dilakukan. Kegiatan ini dilakukan dengan mengamati aktivitas siswa dan guru bersama-sama dengan pelaksanaan Quizizz dalam proses belajar-mengajar. (4). Refleksi. Refleksi adalah kegiatan evaluasi mengenai perubahan yang telah terjadi atau hasil yang diperoleh dari data yang terkumpul sebagai bentuk dampak dari tindakan yang telah dirancang. Refleksi dilakukan untuk mengetahui kelemahan dan kelebihan yang terjadi selama proses pembelajaran. Guru dan peneliti mendiskusikan hasil pelaksanaan pembelajaran dan observasi tindakan pada pelaksanaan siklus I untuk melakukan perbaikan pelaksanaan pembelajaran pada siklus II.

Peserta adalah siswa di kelas 8A dari SMP MTA Gemolong, Sragen Jawa Tengah. Penelitian ini hanya melibatkan satu kelas yaitu Kelas 8A yang terdiri dari 22 siswa. Peneliti ini menggunakan tiga instrumen, yaitu: tes, quesionar, dan lembar observasi. Tes, yaitu teknik pengukuran yang melibatkan berbagai pertanyaan, pernyataan, atau serangkaian tugas yang harus dijawab oleh responden. Sebuah tes adalah alat ukur yang terdiri dari pertanyaan untuk mengumpulkan data yang subjek penelitian harus menanggapi. Tes digunakan untuk mendapatkan membaca prestasi pemahaman 
siswa pada setiap siklus. Dalam penelitian ini tes yang diberikan berupa pre-test dan posttest yang diberikan pada setiap siklus dengan menggunakan Quizizz. Pretest yang dilakukan sebelum pembelajaran, sedangkan post-test diberikan setelah siswa menggunakan Quizziz pada akhir siklus (Junior, 2020). Tes terdiri dari 10 item pilihan dan yang diambil dari para Quizizz sebagai media pembelajaran. Instrumen selanjutnya adalah kuesioner, yang meliputi serangkaian pertanyaan untuk mengumpulkan informasi dari responden. Quesioner diberikan untuk menguji minat siswa dalam menggunakan Quizizz untuk belajar pemahaman bacaan. Quesioner terdiri dari 13 pertanyaan dan siswa harus menanggapi dengan memilih salah satu dari empat pilihan sesuai dengan bagaimana mereka rasakan ketika belajar membaca pemahaman menggunakan Quizizz. Masing-masing pertanyaan diberikan empat pilihan, yaitu "sangat setuju", "setuju", "tidak setuju", dan "sangat tidak setuju". Lembar observasi digunakan untuk membuat catatan kegiatan kelas selama proses pembelajaran (Juniarta et al., 2020). Digunakan untuk merekam perilaku siswa dan kondisi kelas selama kegiatan belajar-mengajar

Data kuantitatif dari respon siswa terhadap Quizizz dianalisis menggunakan software untuk analisis data SPSS V. 16.00. Untuk menghitung mean dan signifikansi pretest dan post-test, peneliti menggunakan uji-t (Nanda et al., 2018). Berikutnya, Quesioner, ada 13 pertanyaan dengan skala 1-4 untuk jawaban pilihan. Skor tertinggi 4 dan skor terendah 1. Oleh karena itu, yang jumlah total dari nilai tertinggi adalah $52(4 \times 13)$ dan skor terendah adalah 13 (1x13). Dalam menentukan interval tiap level dapat digunakan rumus

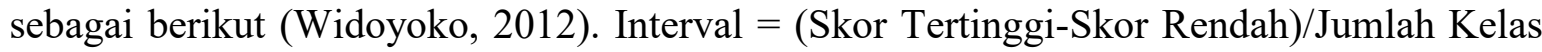
Interval. Dari rumus untuk mencari interval yang ada, dapat dilakukan perhitungan sebagai berikut: Interval $=(52-13) / 4=9,75$. Dari perhitungan untuk mencari jarak interval di atas, tanggapan dapat dikelompokkan ke dalam kategori berikut:

Tabel 1. Kategori dari Response Siswa

\begin{tabular}{ll}
\hline nilai siswa & Kategori \\
\hline $42,25-52$ & Sangat setuju \\
$32,5-42,25$ & Setuju \\
$22.75-32.5$ & Tidak setuju \\
$13-22,75$ & Sangat tidak setuju \\
\hline
\end{tabular}

\section{Hasil Penelitian dan Pembahasan}

Dalam penelitian ini, ada dua jenis data, yaitu data kuantitatif dan data kualitatif. Temuan data kuantitatif dapat diperoleh dari skor pemahaman membaca siswa pre-test dan post-test, sedangkan data kualitatif dapat diperoleh dari angket dan hasil observasi. Data diperoleh dari siklus I dan siklus II. Setiap siklus dilaksanakan dalam tiga kali pertemuan dan memiliki materi yang berbeda. Siklus I tentang struktur dan kebahasaan teks berita dan siklus II tentang menulis teks berita. 
Hasil pre-test pada siklus I menunjukkan bahwa siswa memiliki prestasi belajar bahasa Indonesia yang rendah. Ada tujuh anak lulus kriteria minimum untuk Kelas 8A bahasa Indonesia di SMP MTA Gemolong Sargen, dengan skor 70. Empat siswa memperoleh skor 70, dua siswa memperoleh skor 80, dan satu siswa memperoleh skor 100. persentase siswa yang lulus dari kriteria ketuntasan minimal yang diperoleh dengan membagi jumlah siswa yang menyelesaikan tes ( 7 siswa) dengan jumlah total siswa (22 siswa) dan mengalikan hasil dengan $100 \%$. Persentase siswa yang lulus pre-test adalah $31,82 \%$.

\begin{tabular}{cccc} 
Tabel 2. Data Statistik Hasil Tes Bahasa Indonesia Menggunakan Quizizz \\
\cline { 2 - 3 } & Mean & Skor Minimum & $\begin{array}{c}\text { Skor } \\
\text { Maksimum }\end{array}$ \\
\hline Pre-tes & 57,73 & 20 & 100 \\
Post-test & 75,00 & 40 & 100 \\
\hline
\end{tabular}

Dalam Tabel 2, nilai rata-rata siswa dari pre-test adalah 57,73 , yang dikategorikan sebagai sangat rendah. Dari hasil ini pre-test, dapat disimpulkan bahwa prestasi membaca siswa dengan pemahaman rendah. Oleh karena itu, penting untuk membantu mereka dan memberikan beberapa bentuk bantuan untuk meningkatkan pemahaman membaca (Zhao, 2019).

Dalam siklus ini, masih banyak siswa yang sedang bingung dan tidak dapat fokus pada melakukan tes membaca pada Google Form dan Quizizz . Hal ini kemungkinan karena mereka belum siap dengan kuis yang merupakan media baru bagi mereka dalam belajar membaca pemahaman. Apalagi mereka belum pernah belajar membaca Quizizz. Beberapa dari mereka protes karena penerimaan pada perangkat mereka adalah minim, dan bahwa mereka kuota internet tiba-tiba keluar, dan lainlain. Sedangkan siswa yang kuota internetnya sudah habis tidak siap dan tidak berharap untuk menggunakan kuota internet pribadinya karena belum terbiasa mengikuti pembelajaran online. Pengamat/guru menilai kondisi ini dalam membimbing siswa agar lebih siap menghadapi kuis yang akan datang. Guru juga memotivasi siswa untuk belajar lebih giat dan menyiapkan kuota yang cukup untuk pembelajaran online di masa mendatang. Pada pertemuan kedua, mereka mulai terbiasa menggunakan aplikasi Quizizz. Mereka terlihat sangat antusias dalam mengikuti proses pembelajaran (Juniarta dkk., 2020; Junior, 2020). Karena itu, hasil latihan mereka pada pertemuan kedua sudah mulai membaik. Peningkatan prestasi membaca pemahaman siswa terlihat dari hasil post-test mereka.

Seperti hasil pre-test pada siklus I, tujuh belas siswa lulus kriteria ketuntasan minimal. Ada empat siswa dengan skor 70, delapan siswa dengan skor 80, empat siswa dengan skor 90, dan satu siswa dengan skor 100. Persentase siswa yang lulus dengan kriteria ketuntasan minimal adalah jumlah siswa yang menyelesaikan tes (17 siswa) dibagi dengan jumlah siswa (22 siswa) dan dikalikan 100\%. Persentase siswa yang lulus post-test adalah 77\%, menunjukkan $45 \%$ peningkatan dari pretest persentase (Juniarta et al, 2020;. SMP, 2020). Selanjutnya, pada Tabel 2 terlihat bahwa nilai rata-rata siswa pada post-test adalah 75,00. Dari hasil ini post-test, dapat disimpulkan bahwa prestasi bahasa Indonesia siswa tinggi (Zhao, 2019) dengan peningkatan 17,27 dari pre-test indeks. Tidak pernah, ada satu siswa 
yang tidak meningkatkan membaca pemahaman. Pengaruh pembelajaran menggunakan Quizziz pada siswa membaca prestasi bahasa Indonesia pada siklus I dapat digambarkan sebagai berikut.

Ho: Rata-rata skor pre-test dan rata-rata skor post-test sama.

Ha: Rata-rata skor pre-test dan rata-rata skor post-test tidak sama.

Hasil analisis dengan SPSS . V.16,00 adalah sebagai berikut.

Tabel 3. Hasil Siklus I Analysis t-test

Paired Differences

$95 \%$ Confidence

Interval of the

Differenc

\begin{tabular}{ccccccccc}
\hline & \multicolumn{3}{c}{ Std. error } & & & & Sig. (2- \\
& Mean & Std. Deviasi & Mean & Low & Upper & t & df & tai) \\
\hline Pre-tes - & & & & & & & &
\end{tabular}

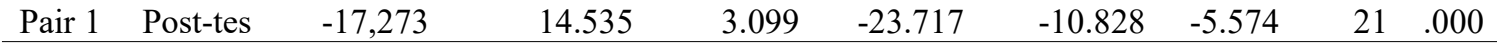

$\mathrm{t}=-5,574, \mathrm{df}=21$, Sig (2-tailed) $=0,000$. Ternyata Sig $=0,000<0,05$ artinya Ho ditolak. Kesimpulan: Rata-rata skor pre-test dan rata-rata skor post-test tidak sama . Tabel 4 menunjukkan sebuah pre-test rata skor dari 57,73 dan sebuah posttest rata skor dari 75,00. Artinya penggunaan Quizizz dalam pembelajaran bahasa Indonesia berpengaruh terhadap hasil belajar bahasa Indonesia siswa pada siklus I.

Tabel 4. Rerata Skor pada Siklus I

\begin{tabular}{|c|c|c|c|c|c|}
\hline & & Mean & $\mathrm{N}$ & Std. Deviasi & Std. Error Mean \\
\hline \multirow[t]{2}{*}{ Pair 1} & Pre-tes & 57,73 & 22 & 18,240 & 3,889 \\
\hline & Post-test & 75,00 & 22 & 14,392 & 3,068 \\
\hline
\end{tabular}

Setelah melakukan post-test, para peneliti mendistribusikan kuesioner untuk belajar tentang minat siswa dalam pembelajaran bahasa Indonesia dengan menggunakan Quizizz. Dapat dilihat pada Bagan 1 di bawah ini.

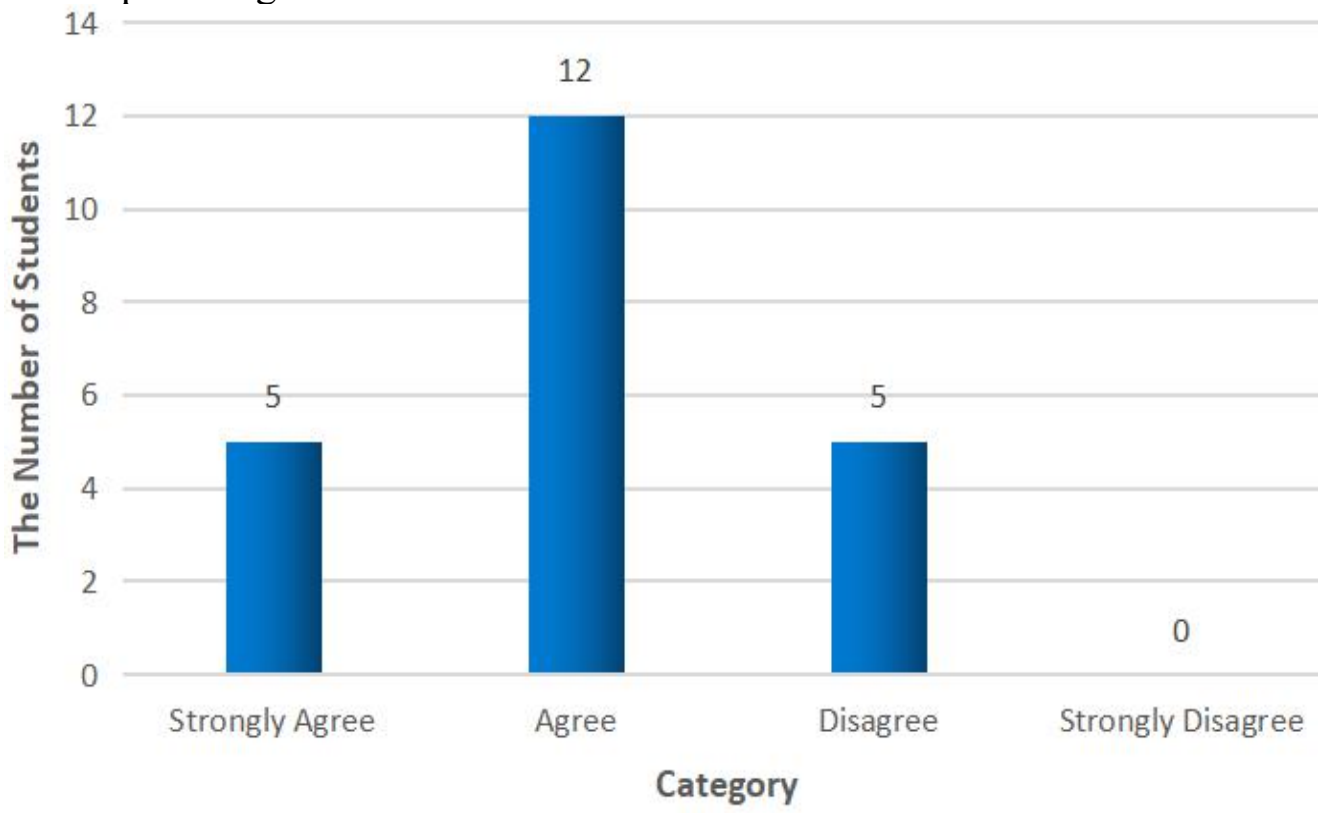

Bagan 1. Tanggapan Kuesioner Siswa pada Siklus I

Lima siswa memilih "sangat setuju", dua belas siswa memilih "setuju", dan lima siswa memilih "tidak setuju". Dengan demikian, 17 siswa menunjukkan tanggapan positif dan hanya lima siswa yang memberikan tanggapan negatif terhadap Quizizz. Hal ini 
dapat disimpulkan bahwa mereka sangat senang dan antusias dalam belajar bahasa Indonesia menggunakan Quizizz (Juniarta et al, 2020;. SMP, 2020) . Dengan demikian, Quizizz juga dapat membantu mereka untuk memahami dan berpikir kritis dalam mengerjakan tes bahasa Indenesia (Puspitayani et al., 2020). Penelitian ini akan dianggap berhasil jika semua siswa bisa meningkatkan prestasi belajar bahasa Indonesia dan semua siswa merespon positif menggunakan Quizizz pada pembelajaran bahasa Indonesia (Nanda et al., 2018). Oleh karena itu, siklus kedua dilakukan untuk menjadi sukses .

Dari hasil dari siklus I, ada satu masalah yang harus diselesaikan dalam siklus II. Masih banyak siswa yang tidak mengerti bagaimana menemukan sinonim dan kalimat implisit karena kosa kata mereka masih kurang. Menurut Basirun (2004), dua indikator umum dalam pemahaman bacaan adalah kemampuan untuk menemukan sinonim atau antonim dari kata tertentu, dan menemukan informasi eksplisit dan implisit. Oleh karena itu, pada siklus II, para peneliti merancang sebagai strategi, yaitu dengan memberikan topik yang akan dipelajari untuk siswa dan meminta mereka untuk mencari informasi tentang topik ini sebelum pelajaran dimulai. Hal ini dilakukan untuk mengefisienkan waktu dan mempermudah aktivitas mereka pada kuis online dalam pembelajaran bahasa Indonesia (Juniarta et al., 2020; Junior, 2020) . Modifikasi ini diterapkan selama proses pembelajaran pada siklus II. Hal tersebut membuat siswa semakin bersemangat dalam mengikuti kelas online (Juniarta et al., 2020). Namun pada pertemuan pertama, mereka masih terlihat kebingungan untuk mengerjakan latihan Quizizz dalam waktu yang singkat. Pada pertemuan berikutnya, mereka lebih santai dalam mengerjakan soal tes bahasa Indonesia di Quizizz karena mereka sudah terbiasa menggunakan Quizizz serta mempelajari topik sebelum pelajaran dimulai (Zhao, 2019). Jadi, ketika mereka mengerjakan post-test pada pertemuan terakhir, mereka mendapat nilai lebih baik daripada nilai pada post-test pada siklus I. Hasil siklus II ada, lima anak-anak lulus kriteria ketuntasan minimal untuk kelas 8A bahasa Indonesia di SMP MTA Gemolong Sragen, yang memperoleh skor 70. Empat siswa memperoleh skor 70, dan satu siswa memperoleh skor 80. Persentase siswa yang lulus kriteria ketuntasan minimal yang diperoleh dengan membagi jumlah siswa yang menyelesaikan tes (5 siswa) dengan jumlah total siswa (22 siswa) dan mengalikan hasilnya dengan 100\%. Persentase siswa yang lulus pretest adalah 22,73 \%. Dalam Tabel 5, nilai rata-rata siswa dari pre-test adalah 60,00, yang dikategorikan sebagai sangat rendah.

Tabel 5. Data Statistik pada Test Membaca Hasil menggunakan Quizizz

\begin{tabular}{cccc}
\hline Tes & Mean & skor minimal & skor maksimum \\
\hline Pre-tes & 60,00 & 40 & 80 \\
Post-test & 81,36 & 60 & 100 \\
\hline
\end{tabular}

Berdasarkan data dari hasil post-test pada siklus II, ada dua puluh satu siswa yang lulus ketuntasan minimal kriteria. Ada lima siswa dengan nilai 70, sembilan siswa dengan nilai 80, empat siswa dengan nilai 90, dan tiga siswa dengan nilai 100 . Jadi, persentase siswa yang lulus adalah banyaknya siswa yang tuntas. tes ( 21 siswa) dibagi dengan jumlah total siswa (22 siswa), dikalikan dengan 100\%. Hasil persentase siswa yang lulus pretest adalah $95 \%$. Ini hasil menunjukkan $18 \%$ peningkatan dari hasil post-test pada siklus pertama. Pada Tabel 5, nilai rata-rata post-test siswa pada siklus II adalah 81,36. Dari hasil ini post-test dapat disimpulkan bahwa prestasi bahasa Indonesia siswa sangat 
tinggi (Juniarta et al, 2020;. Junior, 2020; Zhao, 2019) dengan suatu peningkatan dari 6,36 dari hasil post-test dari siklus I.

Pengaruh pembelajaran menggunakan Quizziz pada siswa membaca prestasi bahasa Indenesia pada siklus II dapat dianalisis sebagai berikut.

Ho: Rata-rata skor pre-test dan rata-rata skor post-test sama.

Ha: Rata-rata skor pre-test dan rata-rata skor post-test tidak sama.

Hasil analisis dengan SPSS . V.16,00 adalah sebagai berikut.

Tabel 6 . Hasil Siklus II Analysis T-test

$95 \%$ Confidence

Interval of the

Difference

\begin{tabular}{llllllll}
\hline & \multicolumn{3}{c}{ Std. Error } & & & Sig. (2- \\
Mean & Std. Deviasi & Mean & Low & Upper & t & df & tailed) \\
\hline
\end{tabular}

$\begin{array}{llllllllll}\text { Pair } 1 & \text { Post-tes } & 21,364 & 60,396 & 1.364 & 24.199 & 18.528 & 15.667 & 21 & .000\end{array}$

$\mathrm{t}=-15.667, \mathrm{df}=21$, Sig (2-tailed) $=0,000$. Ternyata Sig $=0,000<0,05$ artinya Ho ditolak. Kesimpulan: Rata-rata skor pre-test dan rata-rata skor post-test tidak sama . Tabel 7 menunjukkan nilai rata-rata pre-test 60,00 dan nilai rata-rata post-test 81,36 Artinya penggunaan Quizizz dalam pembelajaran bahasa Indonesia berpengaruh terhadap prestasi membaca pemahaman siswa pada siklus II.

Tabel 7. Rerata Skor pada Siklus II

\begin{tabular}{|c|c|c|c|c|c|}
\hline & & Mean & $\mathrm{N}$ & Std. Deviasi & Std. Error Mean \\
\hline \multirow[t]{2}{*}{ Pair 1} & Pre-tes & 60,00 & 22 & 8,729 & 1,861 \\
\hline & Post-test & 81,36 & 22 & 10,821 & 2.307 \\
\hline
\end{tabular}

Persentase ketuntasan pada pra siklus (pre-test siklus I) $=31,82 \%$, persentase ketuntasan pada siklus $\mathrm{I}=77,27 \%$, dan persentase ketuntasan pada siklus II $=95,00 \%$. Artinya telah terjadi peningkatan yang signifikan dalam persentase ketuntasan pembelajaran bahasa Indonesia siswa, sebagaimana disajikan pada Bagan 2.

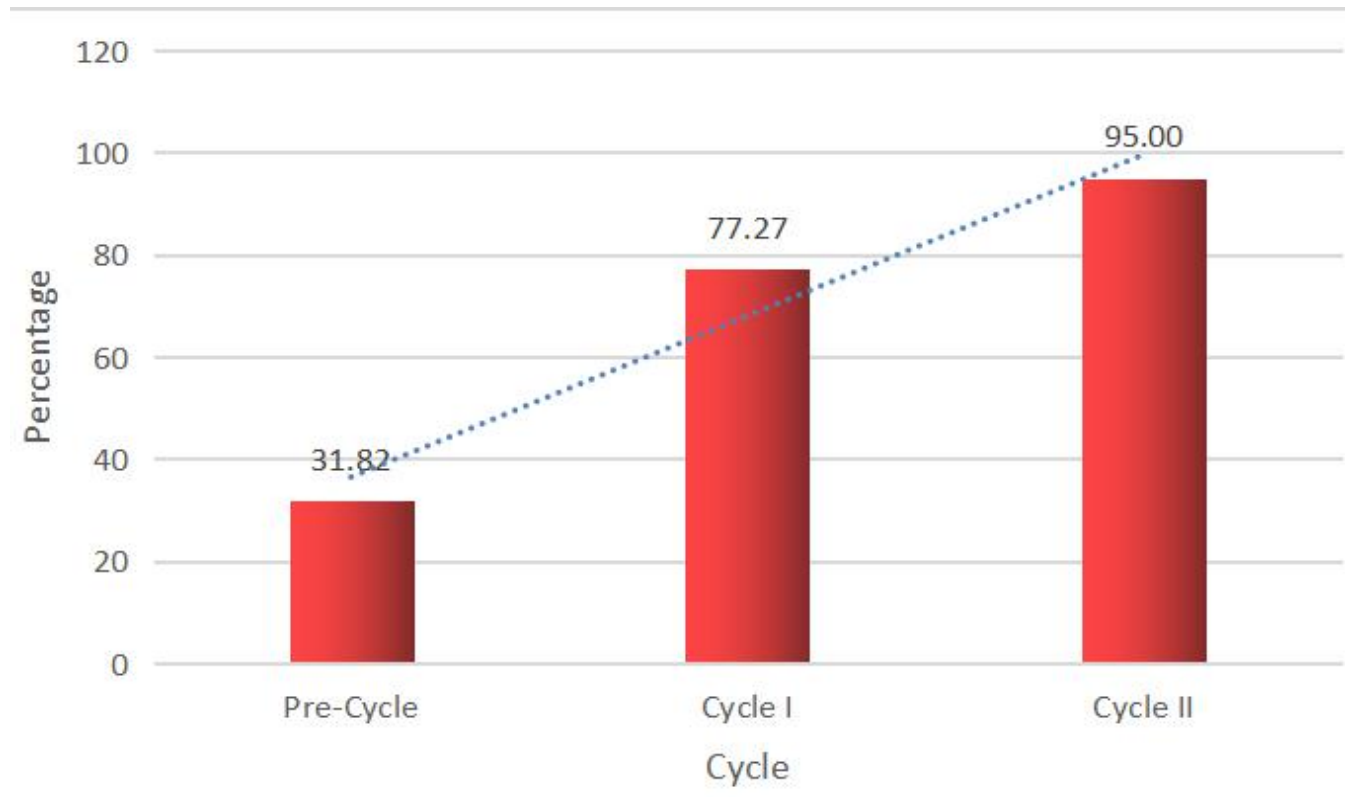

Bagan 2. Persentase Kompetensi di Pra-Siklus, Siklus I, dan Siklus II. 
Setelah melakukan post-test, para peneliti membagikan kuesioner untuk mempelajari minat siswa dalam pembelajaran bahasa Indonesia dengan menggunakan Quizizz, seperti yang ditunjukkan pada Bagan 3 di bawah ini.

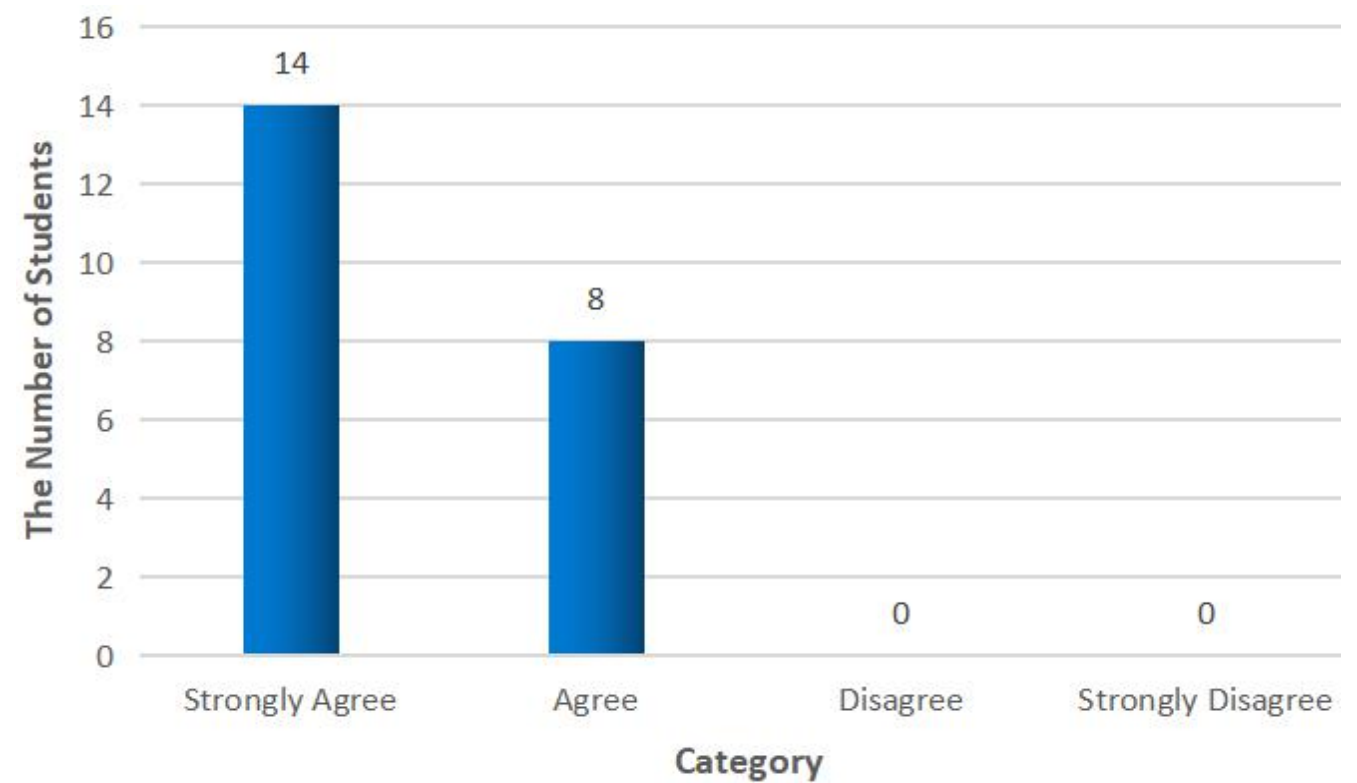

Bagan 3. Respon Kuesioner Siswa pada Siklus II

Empat belas siswa memilih "sangat setuju", dan delapan siswa memilih "setuju". Dengan demikian, semua siswa memberikan respon positif dalam menggunakan Quizizz untuk pembelajaran bahasa Indonesia (Zhao, 2019). Peningkatan tersebut mungkin karena adanya modifikasi pada kelas online pada siklus II. Siswa juga menjadi lebih santai, tenang, dan nyaman dalam mengerjakan tes bahasa Indonesia dengan menggunakan Quizizz. Tidak hanya itu, prestasi membaca mereka juga meningkat (Junior, 2020). Karena tujuan penelitian ini telah tercapai, maka siklus berikutnya tidak perlu dilanjutkan. Hasil penelitian ini mencerminkan sama temuan sebagai studi oleh Priyanti et al. (2019) yang menerapkan pembelajaran terpadu dengan menggunakan Quizizz untuk mengembangkan tugas formatif yang baik dalam mengukur siswa membaca pemahaman. Mereka mengembangkan penilaian formatif baik untuk menilai membaca kompetensi berdasarkan aspek linguistik seperti fungsi sosial, struktur teks, dan bahasa fitur. Mereka membuat tugas formatif online menggunakan Quizizz berdasarkan tuntutan kompetensi dasar yang terdiri dari keterampilan dasar, keterampilan menengah, serta maju keterampilan membaca pemahaman. Hasilnya mereka diyakini untuk membantu guru dalam meningkatkan kompetensi profesional mereka sejak mereka dapat mengembangkan penilaian formatif online mereka menggunakan Quizizz untuk menilai membaca kompetensi sebagai bagian dari proses belajar mereka.

\section{Simpulan dan Saran}


Penelitian ini dilakukan untuk mencoba meningkatkan prestasi siswa dalam bahasa Indonesia dengan menggunakan Quizizz. Quizizz merupakan metode gamifikasi dimana pembelajaran bahasa dirancang dalam bentuk permainan untuk menarik minat siswa dalam pembelajaran bahasa. Biasanya siswa tidak tertarik untuk berlatih mengerjakan tes membaca dan merasa membosankan karena kurangnya kosa kata, yang menghambat mereka dalam memahami makna teks, dan pada akhirnya menurunkan nilai membaca mereka. Oleh karena itu, para peneliti memperkenalkan Quizizz, yang merupakan bentuk dari gamification, dalam belajar membaca. Quizizz memiliki banyak gambar dukungan pemahaman membaca belajar seperti musik, suara yang nyata dari penutur asli, desain warna-warni, dan gambar interaktif untuk berkomunikasi dengan teman-teman, guru, dan lainnya pengguna. Aplikasinya berhasil membuat siswa antusias belajar bahasa Indonesia dan kompetitif dalam melakukan pertanyaan membaca. Hal ini dapat dibuktikan di dalam rata skor dalam pre-test pada siklus I $(57,73)$ yang meningkat menjadi 75,00 pada post-test. Namun demikian, beberapa hasil siswa belum meningkat dari pre-test ke post-test. Peneliti melakukan siklus II untuk memperbaiki kekurangan pada siklus I. Pada siklus II rerata post-test meningkat menjadi 81,36. Hasil uji-t pada siklus I dan siklus II signifikan, dan persentase ketuntasan siswa pada nilai minimal pada siklus I dan siklus II meningkat secara signifikan. Ada respon positif menggunakan Quizizz dari sebagian besar siswa yang terbukti dengan preferensi mereka dalam menggunakan Quizizz untuk pembelajaran bahasa Indonesia di siklus I ("setuju"), yang selanjutnya meningkatkan pada siklus II ("sangat setuju"). Dengan demikian, saya bisa dapat menyimpulkan bahwa menggunakan Quizizz dapat meningkatkan prestasi belajar bahasa Indonesia siswa.

Saran bagi pendidik dan pembaca adalah menggunakan Quizizz dalam pembelajaran bahasa Indonesia untuk meningkatkan motivasi dan prestasi belajar siswa. Sementara itu, saran untuk siswa agar belajar dengan menggunakan Quizizz, karena Quizizz dapat meningkatkan motivasi belajar di kalangan siswa dalam membaca pemahaman, yang pada gilirannya akan meningkatkan prestasi belajar bahasa Indonesia mereka.

\section{Daftar Rujukan}

Alhuwaydi, A. A. (2020). Effect of smartphone flashcard app on saudi undergraduates' vocabulary acquisition in EFL reading classes. Asian EFL Journal.

Alsuhaymi, D. S., \& Alghamdi, A. M. (2021). An investigation of the factors that predict university instructors' intentions to adopt social media into their teaching. Journal of Educators Online. https://doi.org/10.9743/jeo.2021.18.1.7

Aritonang, I. R., Lasmana, S., \& Kurnia, D. (2019). The Analysis of Skimming and Scanning Technique to Improve Students in Teaching Reading Comprehension. PROJECT (Professional Journal of English Education), 1(2), 101-106. https://doi.org/10.22460/project.v1i2.p101-106

Barakati, D. P. (2013). Dampak Penggunaan Smartphone dalam Pembelajaran Bahasa Inggris (Persepsi Mahasiswa). Jurnal Elektronik Fakultas Sastra Universitas Sam Ratulangi. 
Basirun, C. (2004). Speak English Junior High School English Textbook. Jakarta: PT Grasindo.

Davie, N., \& Hilber, T. (2015). Mobile-assisted language learning: Student attitudes to using smartphones to learn English vocabulary. Proceedings of the 11th International Conference on Mobile Learning 2015, ML 2015.

Deterding, S., O’Hara, K., Sicart, M., Dixon, D., \& Nacke, L. (2011). Gamification: Using game design elements in non-gaming contexts. Conference on Human Factors in Computing Systems - Proceedings, 5-8. https://doi.org/10.1145/1979742.1979575

Grabe, W. (2009). Reading in a Second Language Moving from Theory to Practice. In Reading in a Second Language: Moving from Theory to Practice.

Gupta, D., \& Woldemariam, G. S. (2011). The influence of motivation and attitude on writing strategy use of undergraduate EFL students: Quantitative and qualitative perspectives. Asian EFL Journal.

Hamari J, Koivisto J and Sarsa H. (2014). Does gamification work? A literature review of empirical studies on gamification. In: 2014 47th Hawaii international conference on system sciences, Waikoloa Hawaii, USA, 6-9 January 2014, pp.3025-3034. New York: IEEE.

Juniarta, P. A. K., Dewi, K. S., Mahendrayana, G., \& Swandana, I. W. (2020). The Analysis on the Implementation of Mobile-Assisted Language Learning Strategy Through Quizizz Application to Improve Student's Reading Comprehension at Undiksha Singaraja. 394(Icirad 2019), 323-327. https://doi.org/10.2991/assehr.k.200115.053

Junior, J. B. B. (2020). Assessment for Learning With Mobile Apps: Exploring the Potential of Quizizz in the Educational Context. International Journal of Development Research.

Kapp, K. M. (2012). The Gamification of Learning and Instruction (Electronic Reseource): Game-Based Methods and Strategies for Training and Education. In San Fransisco: Pfeiffer.

Kolb, L. (2008). Toys to Tools: Connecting Student Cell Phone to Education in and out of the Classroom. USA: International Society for Technology in Education.

Kolb, L. (2011). Cell Phones in the Classroom: A Practical Guide for Education. USA: International Society for Technology in Education.

Khafaga, A. F., \& Shaalan, I. E. N. A. W. (2021). Mobile learning perception in the context of COVID-19: An empirical study of saudi EFL majors. Asian EFL Journal.

Kukulska-Hulme, A. (2009). Will mobile learning change language learning? ReCALL, 21(2), 157-165. https://doi.org/10.1017/S0958344009000202

Kukulska-Hulme, A., \& Bull, S. (2009). Theory-based Support for Mobile Language Learning: Noticing and Recording. International Journal of Interactive Mobile Technologies (IJIM). https://doi.org/10.3991/ijim.v3i2.740

Lai, C., \& Zheng, D. (2018). Self-directed use of mobile devices for language learning beyond the classroom. ReCALL. https://doi.org/10.1017/S0958344017000258

Liu, D., Santhanam, R., \& Webster, J. (2017). Toward meaningful engagement: A framework for design and research of gamified information systems. In MIS Quarterly: Management Information Systems. https://doi.org/10.25300/MISQ/2017/41.4.01 
Loewen, S., Crowther, D., Isbell, D. R., Kim, K. M., Maloney, J., Miller, Z. F., \& Rawal, H. (2019). Mobile-assisted language learning: A Duolingo case study. ReCALL, 31(3), 293-311. https://doi.org/10.1017/S0958344019000065

Mei, Sou Yan, \& Zalika. Implementing Quizizz as Game Based Learning in Arabic Classroom. European Journal of Social Sciences Education Research, 1(2), 70-88.

Mobinizad, M. M. (2018). The Use of Mobile Technology in Learning English Language. Theory and Practice in Language Studies. https://doi.org/10.17507/tpls.0811.10

Mohamad, M., Arif, F. K. M., \& Noor, N. M. (2020). Online game-based formative assessment: Distant learners post graduate students ${ }^{\text {ee }}$ positive perceptions towards quizizz. International Journal of Scientific and Technology Research.

Nanda, S. R., Abdul, N. B., \& Daddi, H. (2018). The Use of Quizizz Application in Improving Students' Reading Comprehension Skill at SMKN 3 Takalar : An Experimental Research. Journal of Computer Interaction in Education.

Pang, J. (2008). Research on Good and Poor Reader Characteristics: Implications for L2 Reading Research in China. Reading in a Foreign Language.

Peng, H., Jager, S., \& Lowie, W. (2020). Narrative review and meta-analysis of MALL research on L2 skills. ReCALL. https://doi.org/10.1017/S0958344020000221

Peters, C., \& Bodkin, C. D. (2021). An exploratory investigation of the uses and gratifications of apps for student learning. Journal of Educators Online, 18(1), 73-88. https://doi.org/10.9743/jeo.2021.18.1.5

Pitoyo, M. D., Sumardi, \& Asib, A. (2020). Gamification-based assessment: The washback effect of quizizz on students' learning in higher education. International Journal of Language Education, 4(1), 1-10. https://doi.org/10.26858/ijole.v4i2.8188

Pourhosein Gilakjani, A., \& Sabouri, N. B. (2016). A Study of Factors Affecting EFL Learners' Reading Comprehension Skill and the Strategies for Improvement.

International Journal of English Linguistics. https://doi.org/10.5539/ijel.v6n5p180

Prensky, M. (2001). Digital Natives, Digital Immigrants Part 1. On the Horizon. https://doi.org/10.1108/10748120110424816

Priyanti, N. W. I., Santosa, M. H., \& Dewi, K. S. (2019). Effect of Quizizz Towards the Eleventh-Grade English Students' Reading Comprehension in Mobile Learning Context. Language and Education Journal Undiksha, 2(2), 71-80. https://doi.org/10.23887/leju.v2i2.20323

Puspitayani, D. M. A., Putra, I. N. A. J., \& Santosa, M. H. (2020). Developing Online Formative Assessment Using Quizizz for Assessing Reading Competency of the Tenth Grade Students in Buleleng Regency. Jurnal Imiah Pendidikan Dan Pembelajaran.

Rios, T., Elliott, M., \& Mandernach, B. J. (2018). Efficient instructional strategies for maximizing online student satisfaction. Journal of Educators Online. https://doi.org/10.9743/jeo.2018.15.3.7

Suwarto, D. (2013). Pengembangan Tes Diagnostik Dalam Pembelajaran. Yogyakarta: Pustaka Pelajar.

Suwarto, S. (2017). Pengembangan tes ilmu pengetahuan alam terkomputerisasi. Jurnal Penelitian dan Evaluasi Pendidikan, 21(2), 153-161.

Villaflor, G. M. G. (2019). MALL (mobile-assisted language learning) wows and woes of ESL teachers. Asian EFL Journal.

Wang, S., \& Higgins, M. (2006). Limitations of mobile phone learning. The JALT CALL Journal. https://doi.org/10.29140/jaltcall.v2n1.18 
Wibawa, R. P., Astuti, R. I., \& Pangestu, B. A. (2019). Smartphone-Based Application "quizizz" as a Learning Media. Dinamika Pendidikan, 14(2), 244-253. https://doi.org/10.15294/dp.v14i2.23359

Widoyoko, E. P. (2012). Teknik penyusunan instrumen penelitian. Yogyakarta: Pustaka Pelajar.

Yan mei, S., Yan Ju, S., \& Adam, Z. (2019). Implementing Quizizz as Game Based Learning in the Arabic Classroom. European Journal of Social Science Education and Research, 1(2), 70-88. https://doi.org/10.2478/ejser-2018-0022

Zaccoletti, S., Altoè, G., \& Mason, L. (2020). Enjoyment, anxiety and boredom, and their control-value antecedents as predictors of reading comprehension. Learning and Individual Differences, 79(February 2019), 101869. https://doi.org/10.1016/j.lindif.2020.101869

Zakaria, N. Y. K., \& Hashim, H. (2020). Game-Based Assessment in Academic Writing Course for Pre-Service Teachers. TESOL International Journal.

Zhao, F. (2019). Using quizizz to integrate fun multiplayer activity in the accounting classroom. International Journal of Higher Education.

https://doi.org/10.5430/ijhe.v8n1p37. 